\title{
An Intergroup Contact-Theory Framework for Evaluating Racial Climate on Predominantly White College Campuses
}

\author{
Tabbye M. Chavous ${ }^{1,2}$
}

\begin{abstract}
This study examined the association of racial climate to social integration outcomes among 215 African American students and 144 White students from a predominantly White university. Presented is preliminary evidence regarding the utility of an ecological approach based on Allport's (1954) intergroup contact theory in examining students' climate perceptions and their impact. Responses to a racial climate scale previously used in secondary settings were collected from participants, and, through factor analysis, a revised scale was developed. The revised scale showed evidence for five subscales assessing perceived intergroup interactions on campus at individual and institutional levels, as well as individuals' personal intergroup interactions. Group differences were found for the subscales and in relationships between subscales and college integration outcomes. Findings suggest the importance of understanding college climate at interpersonal and institutional levels and of assessing impact for both majority and minority students.
\end{abstract}

KEY WORDS: college students; racial climate; intergroup contact.

In this paper, the ways that African American and White students attending a predominantly White college institution (PWI) perceive and experience their campus racial climate are examined using a framework that emphasizes perceptions of the normative quantity and quality of intergroup relations on campus. Although the racial compositions of PWI settings are becoming more ethnically diverse, this has not necessarily translated into increased intergroup interactions or lessened racial tensions on campus. In fact, diversity related issues continue to be primary sources of conflict on campuses across the country (Gurin, Dey, Hurtado, \& Gurin, 2002; Levine \& Cureton, 1998). The college/university campus represents a distinct type of community setting, with a climate created and perpetuated by physical structures, policies, and social norms that guide its

\footnotetext{
${ }^{1}$ School of Education, Educational Studies, Combined Program in Education and Psychology, University of Michigan.

${ }^{2}$ To whom correspondence should be addressed at University of Michigan, School of Education, 610 E, University, Ann Arbor, Michigan 48109-1259; e-mail: tchavous@umich.edu.
}

functioning. On PWI campuses, issues related to race often are interwoven into academic and social domains directly and indirectly (e.g., through class curricula, discussion of current events, institutional policy, etc.) resulting in an institutional climate where race is made very salient to minority and majority group members. Thus, of particular relevance for community psychologists is the idea that PWI campuses are settings where informal and formal structures and norms around race and intergroup interactions are conveyed to individual members and shape their experiences and subsequent behaviors in the settings.

\section{Racial Climate and Intergroup Relations on College Settings}

The climate of an institution can be conceptualized as a psychologically meaningful representation of the institution's environment (Pargament, Silverman, Johnson, Echemendia, \& Snyder, 1983). Studying the climate of an institution provides insight into the culture of a setting, by examining the 
beliefs, attitudes, values, and expectations shared by members of the institution that are sustained over time (Schein, 1985). Climates represent the observable practices, routines, and behaviors that act to socialize and perpetuate cultural beliefs and values to individuals in a setting (Guion, 1973). Models of school organizational climate have been used to describe the social and academic systems that make up school settings in ways that parallel the ways psychologists describe human personalities and attributes (e.g., Halpin \& Croft, 1963; Trickett \& Moos, 1973). The climate of a setting can be viewed, for example, as supportive or non-supportive, controlling or open, or as embodying particular ideologies or philosophies around the ways its members should interact. Thus, the examination of the racial climate of a college or university entails the examination of the beliefs, attitudes, values, and expectations shared by students at the institution that are sustained over time.

Research suggests that White students and ethnic minority students at the same institution often experience different racial climates. In general, White students tend to report more positive perceptions of intergroup relationships and diversity norms at their institutions than do African Americans (e.g., Ancis, Sedlacek, \& Mohr, 2000). Some research suggests that students may be similar in their views about particular aspects of the environment, but they may differ regarding other aspects of the racial climate. Loo and Rolison (1986) for instance, found that minority students (African Americans, Chicanos, and Asian Americans) and White students were in agreement regarding the existence of sociocultural difficulties among students, but that White students perceived that there were greater levels of university support for minorities than the ethnic minority students perceived. Racial group differences regarding the salience of race may account in part for race differences in perceptions of the racial climate. Because race is a more salient identity for ethnic minorities than Whites (e.g., see Phinney, Ferguson, \& Tate, 1997; Crocker \& Luhtanen, 1990) minority college students may be aware of more complex ways that race can impact their lives than White college students. Ethnic minority students are more likely than White students to consider both individual-level interactions and structural/institutional factors in evaluating the ways race functions on their college campus (Blauner, 1989). In contrast, White students are more likely to think about intergroup relations on campus only in terms of the nature of interactions among individuals (Blauner, 1989). Thus, they are more likely to view claims of structural or institutional racism by minority students to be exaggerated (Essed, 1991; Kluegel \& Bobo, 1993).

Along with showing racial differences in the perception of racial climate, research suggests that college students' perceptions of norms around race on campus have implications for important academic and social outcomes for ethnic minority students, such as performance and persistence (Nettles, 1988; Zea, 1997; Cabrera et al., 1999); enhanced interaction with teachers and White peers (Allen, 1988; Davis, 1995; Fleming, 1984; Nettles, 1988); and college involvement (Nettles, 1988, 1991; Tracey \& Sherry, 1984). Interestingly, the association between White students' perception of their college's racial climate and their own college adjustment outcomes has received little attention from researchers. This omission seems problematic in light of the fact that minority group members who have been traditionally underrepresented in higher education are attending PWIs in greater numbers (Harvey, 2001), resulting in more diverse campuses and more opportunity for interaction among African American and White college students. Furthermore, while research in the past two decades has suggested that White students are overall apathetic about issues of multiculturalism and diversity on their campuses (Baxter Magolda, 1997; Levine \& Cureton, 1998), race and race relations are extremely salient issues on PWI campuses. The current debates over college admissions policies and affirmative action, for instance, have resulted in open discourse around race in many forms (e.g., class curricula, student activism activities, media coverage, academic talks/presentations) making it likely that most White students would at least be exposed to some discussion of race on their campus. Such exposure to racial issues is likely to have important consequences for students. Research by Helm, Sedlacek, and Prieto (1998) suggests that the way race is discussed and perceived on campus has implications for the social and academic adjustment for both minority and majority group members. As such, it is important to investigate whether White students' perceptions of the overall racial climate of their campus have a similar association with their social adjustment and integration on campus as it does for ethnic minority students. In one of few studies examining the impact of racial climate with a White sample, Canabal (1993) found that racial climate (as evaluated by perceptions of diversity support by the university) was more predictive of institutional attractiveness for 
Hispanics, African Americans, and White females than for White males. Cabrera and colleagues (1999) reported significant relationships between perceptions of discrimination on campus and perceived intellectual development and institutional commitment for Whites and African Americans, but the relationships were weaker for White students. In contrast, campus discrimination showed a strong relationship to social experiences for African Americans, but not for White students. The research suggests particular aspects of racial climate related to intergroup relations may relate differentially to attitudes, behavior, and adjustment for different types of students.

While it is important to investigate how individuals' perceptions of racial climate are related to academic and social outcomes for students, from a community psychology perspective, equal relevance also should be given to understanding the sociocultural backgrounds that individuals bring to their college environment as well as to the contexts they experience within their college setting (Trickett, 1996). Recent studies reveal that students reporting more diversity experiences prior to college (e.g., intergroup friendships) had more diversity experiences on campus (Hurtado, Engberg, Ponjuan, \& Landreman, 2003; Nagda, Gurin, \& Johnson, 2004). D'Augelli and Hershberger (1993) and Davis (1995) suggest that African American students whose precollege backgrounds are more racially congruent with the PWI environment show better social and academic integration. Thus, individuals' prior experiences may influence how they perceive race as functioning on campus, as well as the ways they respond and adjust to the environment.

\section{An Intergroup Contact Theory Approach to Studying Racial Climate}

A review of the research literature on racial climate yields several operationalizations of the construct. For example, racial climate has been operationalized as: trust and interaction among racial groups on campus (Hurtado, 1994), peer relations and attitudes of university government and personnel (Johnson-Durgans, 1994), and the existence of diversity in student body, faculty, and administration (Canabal, 1993). While the racial climate of college settings often is discussed in terms of a single phenomenon that is "positive" or "negative," the varying conceptualizations of racial climate in the research literature suggest that the construct is comprised of a number of interrelated, but conceptu- ally distinct, components that tap into the underlying values and philosophies of the setting. As a result, it is important that measures of racial climate capture this complexity. Otherwise, we will be hard pressed to understand nuanced relationships between various aspects of racial climate and various outcomes. Using unidimensional measures such as the proportions of minority students as a single indicator of racial climate severely limits our understanding of seemingly contradictory findings. Research linking the racial compositions of school environments to academic and social outcomes for African American students is equivocal (Gray-Little et al., 1997; Nettles, 1988; Tinto, 1987). Some research suggests that having racially integrated schools can relate to positive intergroup interactions (e.g., Gray-Little et al., 1996) or to negative intergroup interactions (e.g., Nettles, 1991). These findings illustrate the importance of distinguishing among the possibility for intergroup interaction, the actual amount of intergroup interaction, and the nature of the intergroup interaction in assessing racial climate. Unfortunately, at present, there is no single conceptual model or measure within the research literature on college racial climate that captures the multi-faceted nature of the construct.

The contact hypothesis first proposed by Gordon Allport (1954) and since refined by a host of others (e.g., Brewer, 1996; Cook, 1985; Jones, Lynch, Tenglund, \& Gaertner, 2000; Pettigrew, 1998; Cook, 1985; Stephan, 1987) provides a relevant conceptual frame for studying racial climate. Allport's contact hypothesis has been the prevailing framework for understanding when contact between members of unequal status groups will lead to a reduction of prejudice since it was first articulated in the early 1950 s (Allport, 1954). In discussing the effects of desegregation in schools, Allport challenged the idea that successful school racial integration would occur simply as a function of African Americans and Whites sharing the same environment. He argued that individuals would not change stereotypical thinking simply through involuntary associations alone. Because educational settings serve to socialize individuals regarding the norms around which individuals and groups should or should not interact, Allport suggested that successful integration would occur only if certain conditions in which the intergroup interactions occurred are met. Allport and others who have built upon his theory have delineated the following conditions as necessary for intergroup contact to lead to successful integration: 1) meaningful 
associations among members of different groups; 2) interdependence among group members in reaching and maintaining common goals; 3 ) similar level of social status in the environment; and 4) the encouragement of positive intergroup interactions by the institution. These conditions represent a framework for representing the multifaceted nature of racial climate. It is likely that individuals within and across racial groups vary in their perceptions of the extent to which their university racial climate has met each of the conditions as a function of individual and racial group differences in background characteristics and current experiences with individuals of other groups. It is also likely that students' perceptions regarding each of the conditions will differentially predict student outcomes across conditions and perhaps across groups.

Although much of the research focusing on the contact hypothesis has been conducted in the field of social psychology, there already exists evidence of the relevance of the contact hypothesis for understanding students' perceptions of racial climate in their educational settings. A number of studies have utilized measures of racial climate that were related to specific dimensions of the contact hypothesis. In a sample of high school students, Bullock (1978) found that for African American students, contact with Whites alone did not predict social tolerance, but individual contact and perceptions of equal status among African Americans and Whites were positively related to social tolerance. Similarly, in a study of students from a multicultural high school, those who viewed their high school as one group or different groups on the same team felt more positively about other groups than those who viewed groups as functioning separately (Gaertner, Rust, Dovidio, Bachman, \& Anastasio, 1994). College research indicates that students who perceived their campus environment as being supportive of racial diversity and intergroup relations were more open to associating with students from racial and ethnic groups that differed from their own (Astin, 1993; Hurtado, 1992; Pascarella, Edison, Nora et al., 1996). Perceiving the college environment as nondiscriminatory also has been related to students' positive intergroup attitudes on campus (Whitt, Edison, Pascarella, Terenzini, \& Nora, 2001).

Green, Adams, and Turner (1988) created a school interracial climate measure in which they operationalized Allport's framework using four intergroup contact criteria and examined their relationships with various school outcomes in African
American and White middle school students (Green et al., 1988). The authors developed separate subscales to assess students' perceptions of the extent to which the racial climate of their school met each of four conditions proposed by the contact hypothesis. They found that students who believed that both relational conditions (perceptions of interactions among different groups as a school norm, interdependence of groups) and structural contact conditions (equality among groups, and school support for group interactions) were met in their school had higher quality of school life scores and higher sense of academic self-efficacy than those who endorsed the existence of fewer criteria. Other researchers have evaluated each of the criteria more recently with elementary students using the Green et al. (1988) measure and find positive associations with school adjustment outcomes, but single composite scores across the criteria were used when reporting racial climate relationships and outcomes (e.g., Marcus-Newhall \& Heindl, 1998; Wittig \& GrantThompson, 1998). To date the measure has not been used with a college sample.

The present study extends the work of Green and colleagues (1988) by revising their measure so that it is appropriate for a college sample. In adapting their measure, the present study investigates both its construct and external validity. Consistent with the multidimensional nature of the scale, the study also will use students' scores on the individual subscales independently and not aggregated together into a sum score. Such an approach allows for the examination of ways that various subscales independently and synergistically predict a particular outcome. It also allows for the possibility that different dimensions of racial climate may be associated with different phenomena. Finally, the study extends the work of Green et al. by distinguishing between college students' perceptions of their institution's racial climate and their own intergroup experiences at the institution. Some of the current research on racial climate conflates individuals' perceptions of racial climate with individuals' own experiences interacting with members of other racial groups (e.g., Pewewardy \& Frey, 2002). Such a conflation does not allow for the examination of the relationship between the two constructs.

\section{STUDY OBJECTIVES}

The present study introduces a new approach to operationalizing college students' perceptions of 
racial climate with the ultimate goal of better understanding racial differences in perceptions of racial climate and their consequences. With this in mind, the present paper has four objectives. The first objective is to investigate the underlying factor structure of a measure of racial climate that is being adapted for use with college students and which is based on Allport's contact hypothesis. In doing so, the present paper examines whether the underlying factor structure of the measure is valid for both African American and White college students. The second objective is to explore whether there are differences in the ways in which African American and White students perceive their racial climates across the different conditions proposed by the contact hypothesis. The third objective of the study is to investigate the relationship between individuals' demographic and racial backgrounds and their racial climate perceptions. The final objective is to examine the extent to which students' perceptions of different aspects of the racial climate predicted social integration (organizational involvement), psychological integration (sense of community), and intergroup attitudes (orientation toward other ethnic/racial groups) across racial groups.

\section{METHOD}

\section{Participants}

The present study was part of a larger study focusing on the life experiences of African American college students during the 1997-1998 academic year. The sample consisted of 215 African American and
144 White undergraduate students from a large, public predominantly White public university in the southeast United States. African American students made up $9 \%$ of the student population, White students represented $88 \%$, and all other ethnic groups made up $3 \%$ of the institutions' racial composition. The sample was primarily female, with 86 male students (63 African American and 23 White) and 273 female students (152 African American and 121 White). White students were sophomore level (class year $M=1.78, S D=1.02$ ) on average, while the African American sample averaged junior class level (class year $M=2.72, S D=.92$ ). Table I provides descriptive information on student background characteristics.

\section{Procedure}

Participants were recruited from introductory psychology and 200-level psychology classes, through advertisements placed in various areas of campus, and through electronic mail postings to academic department sites. The methods of recruiting resulted in a diverse sample with regard to class year and major (majors from various disciplines from the social sciences to business to engineering were represented). All students were recruited from the same types of settings using the same sampling methods, but because the investigator's larger study centered around issues of ethnicity and college perceptions among African American students, higher numbers of this group were recruited. Thus, the proportion of African Americans in the present study sample is higher relative to Whites in the student body.

Table I. Means and Standard Deviations for Demographic Background Variables

\begin{tabular}{|c|c|c|c|c|}
\hline Variable & Range & $\begin{array}{l}\text { Entire sample } \\
\qquad M(S D)\end{array}$ & $\begin{array}{l}\text { White students } \\
\qquad M(S D)\end{array}$ & $\begin{array}{l}\text { African American } \\
\text { students } M(S D)\end{array}$ \\
\hline Family income & $\begin{array}{l}1-12 \\
\quad \text { below } \$ 4,999 \text { to } \\
\text { above } \$ 105,000 \text { ) }\end{array}$ & $\begin{array}{l}8.00(3.07) \\
\quad(\text { about } \$ 65,000)\end{array}$ & $\begin{array}{l}9.04(2.91)^{*} \\
\quad(\text { about } \$ 75,000)\end{array}$ & $\begin{array}{l}7.40(3.01) \\
\quad \text { (about } \$ 58,000)\end{array}$ \\
\hline Mother's education & $\begin{array}{l}\text { 1-8 } \\
\text { (some high school } \\
\text { to } \mathrm{PhD} / \mathrm{MD} \text { ) }\end{array}$ & $\begin{array}{l}4.48(1.63) \\
\quad(\text { college diploma })\end{array}$ & $\begin{array}{l}4.41(1.45) \\
\quad \text { (college diploma) }\end{array}$ & $\begin{array}{l}4.53(1.74) \\
\quad \text { (college diploma) }\end{array}$ \\
\hline High school GPA & $1-4$ & $3.65(.26)$ & $3.75(.34)^{*}$ & $3.61(.18)$ \\
\hline Percentage African & $\begin{array}{c}1-5 \text { (1: less than } 20 \% \\
\text { to } 5: \text { over } 80 \%)\end{array}$ & $2.19(1.54)$ & $1.53(.52)^{*}$ & $2.83(1.66)$ \\
\hline \multicolumn{5}{|c|}{ Americans in neighborhood } \\
\hline Percentage African & $\begin{array}{l}1-5 \text { (1: less than } 20 \% \\
\text { to } 5 \text { : over } 80 \%)\end{array}$ & $2.23(1.32)$ & $1.63(.70)^{*}$ & $2.33(1.32)$ \\
\hline Americans in high scho & & & & \\
\hline
\end{tabular}

*Indicates significant differences in means at $p<.05$ level. 
Given the overall low representation of African American students at the university, their numbers in the present sample makes them more substantially representative of the larger African American student population at the college at the time. While the White student sample is smaller, because all students were recruited using the same methods and in similar settings, there is no systematic reason that the students would differ from other White students at their institution (in fact, the resulting samples of African American and White students were comparable to the larger student population of African Americans and Whites in terms of their average socioeconomic background characteristics based on university statistics on entering student characteristics for that academic year).

All participants completed study measures in scheduled group administration sessions. Once students agreed to participate, they were asked to sign a consent form for their participation. White and African American participants completed identical measures assessing college perceptions, organizational involvement, and intergroup attitudes. The psychology pool participants received one (1) course credit for their participation. Other participants received $\$ 5$ to participate (students who received payment did not differ significantly from those who received credit along any of the study variables). All participants were assured that all information given would be kept confidential and that their participation was voluntary. Following completion of the measures, all participants were debriefed.

\section{Measures}

\section{Demographic Background Characteristics}

Students completed a demographic measure in which they provided information about their precollege backgrounds. Information obtained included class year, gender, parental education levels, household income, and high school grade point average. Table I summarizes the demographic characteristics of the data sample.

\section{Racial Background Characteristics}

Information about students' pre-college contact with other racial groups was obtained from students' reports of the racial make-up of their neighborhood and high school. Respondents indicated the racial composition in the two settings on a 1-5 categorical scale, where 1 indicated " $0-20 \%$ African American" and 5 indicated " $80-100 \%$ African American."

\section{College Racial Climate}

Information about students' perceptions of their university racial climate was obtained using a School Interracial Climate Scale (SIRC) (Green et al., 1988). The scale evaluates criteria based on Allport's (1954) intergroup contact hypothesis. The SIRC was developed for secondary students and has shown adequate reliability with that population. Several items were modified to be more appropriate for college students, and analyses were conducted to determine factor structure and internal validity for this population. Four subscales evaluated campus perceptions regarding: (1) association, (2) equal status, (3) interdependence, and (4) university supportive norms. A fifth subscale, personal association, assessed respondents' personal intergroup contact on campus. Participants responded to items on a 7-point likert scale indicating 1 (strong disagreement) to 7 (strong agreement). Example items include: "Blacks and Whites at my university have important things to offer each other" (Interdependence); "This university encourages students to make friends with students of different races" (Supportive Norms); "Students of different races don't have much to do with each other at my university" (Association); "Instructors at my university pay attention to both Black and White students" (Equal Status); "At my university, I often go through a whole day without interacting with someone from another group" (Personal Association). Each subscale showed good internal consistency (Cronbach's $\alpha$ s for the association, equal status, interdependence, and university norms subscales were $.88, .78, .84, .80$, and .80 , respectively).

\section{Social Integration-Involvement in Cultural/Multicultural Organizations}

Organizational involvement was an indicator of students' social integration in this study and was assessed in two ways. For White students, involvement in organizations that included substantial proportions of other ethnic groups was evaluated. Students were asked to list the organizations in which they were involved and to indicate the percentage of the group that was made up of members of other racial groups (on a 5-point scale ranging from 1 (less than $20 \%$ ) to 5 (over $80 \%$ ). The percentage of 
organizations made up of over $20 \%$ of other groups represented the diverse organization variable. For African American students, the percentages of multicultural/racially mixed groups (over $20 \%$ African American, but less than $80 \%$ ) as well as the percentage of ethnic group affirming organizations (over 80\% African American) were assessed. Organizations that were considered as ethnic affirming were those whose purpose was to specifically support and nurture African American students (e.g., Black Student Government, Black pre-med and engineering associations) and/or whose group composition was more than $80 \%$ African American. Other organizations with diverse racial representation were considered multicultural groups. A composite variable was then created to represent percentage of African American or multicultural organizations. Thus, in subsequent analyses, a single organizational variable (group affirming/multicultural organizations) was utilized.

The variable coding scheme for organizational involvement was based on examination of students' reported organizational involvement, which revealed that African American students were involved either in predominantly African American organizations or predominantly White organizations (less than 20\% African American). Similarly, White students reported few predominantly other group organizations, but were involved in either mixed-racial group or predominantly White organizations.

Students also were asked if they were members of a Greek fraternity/sorority and of a varsity athletic team. Given the substantial time and effort associated with these types of organizations (Lounsbury \& DeNeui, 1996), membership in a Greek organization or athletics was weighted as two organizations in students' total number of organizations.

\section{Psychological Integration-Sense of Community}

Participants' feelings of attachment and belonging to their university were assessed using the Psychological Sense of Community Scale. The 12-item scale is based upon Lambert's and Hopkins's (1995) Psychological Sense of Community Scale used in organizational settings. Example items include: "[My University] values my contributions to it," "I feel emotionally attached to [My University]," and "I feel a sense of community with others at [My University]." Participants responded to items along a 7-point likert scale, indicating the extent to which they agreed or disagreed with the item statements. Cronbach's $\alpha$ indicated high internal consistency for the scale $(\alpha=.83)$.

\section{Intergroup Orientation}

The extent to which students had attempted to learn about other ethnic groups was assessed using the "Other Group Orientation" subscale of Phinney's (1992) Multiethnic Ethnic Identity Measure. Three items on a 1-4 likert scale assessed individuals' engagement in behaviors to learn about traditions, values, or beliefs other ethnic groups. Cronbach's $\alpha$ coefficient (.79) indicated good internal consistency among items. Higher scores indicate more intergroup exploration.

\section{RESULTS}

\section{Racial Climate Scale Development}

Because the SIRC has not been used with college students, factor analysis was performed to examine the psychometric properties of the measure for the present population. A principal axes factor analysis with orthogonal rotation was performed on the sample items, and a five-factor solution seemed most satisfactory when evaluated by criteria summarized in Pedhazur and Schmelkin (1991). Overall, the orthogonal solution seemed to provide a good simple structure, as there were few items with high loadings on more than one factor. Furthermore, the first four factors were consistent with the four contact theory criteria measured in the original scale by Green et al. (1988). The first factor of the analysis was composed of items that assessed whether groups were treated equally at the university, and was labeled "Equal Status." The second factor, "Association," consisted of items that tapped into the amount of socialization and contact between African American and White students. The third factor included items that indicated the extent to which groups were dependent and worked toward common goals (Interdependence). The fourth factor was labeled "University Norms," and evaluated the extent to which instructors and the university administration encouraged intergroup interactions.

However, the present study and college sample did differ from past study with the measure in that a separate, fifth factor emerged. This factor differed 
conceptually from the other four factors as it consisted of items that evaluated students' personal interactions with other racial groups. In contrast, items for the other four factors assessed individuals' perceptions of how different groups interact in the campus environment. This fifth factor, labeled "Personal Association," consisted of three items. In previous use of the measure with primary and secondary students, the items loaded on the "Intergroup Association" scale. One possibility is that the older adolescents in the present sample may be more able to distinguish their own intergroup contact from their perceptions of how most people in their school interact with other groups than the middle school and elementary students studied in previous work, or younger adolescents may be more likely to conform their intergroup behavior to match perceived norms (e.g., Berndt, 1979). For either possibility, the analyses provide support for the importance of distinguishing individuals' perceptions of intergroup association as a normative practice on campus from their own intergroup behavior.

Factor analyses were conducted separately for African American and White students for the scale items and resulted in identical factor structures for both groups. Therefore, factors and item loadings were reported for the full sample. Items that con- stituted the five factors were ordered according to the size of the loading on each factor. Those items with loadings greater than .40 on a factor were selected to represent that factor as subscales on the final scale. The final scale had two main componentsa Climate Perceptions component made up of four subcomponents based on Allport's framework (Intergroup Association, University Norms, Intergroup Interdependence, and Equal Status) and a Personal Contact component evaluated by the items in the Personal Association factor. The final racial climate scale for the present study consisted of 30 items. Internal consistency for subscales was calculated using Cronbach's $\alpha$. Results indicated high reliabilities and were similar for African American and White participants ( $\alpha$ s ranged from .78 to .88).

\section{Group Differences in Racial Climate Perceptions}

To assess differences between groups in perceptions of racial climate, a Multivariate Analysis of Co-Variance (MANCOVA) was performed with race and class year as the independent variables and the four perception subscales and the personal intergroup contact subscale as dependent variables (see Table II). Family income, mother education,

Table II. Summary of Multivariate Analysis of Co-Variance Examining Racial Climate Subscales by Race

\begin{tabular}{|c|c|c|c|c|c|}
\hline & $\begin{array}{l}\text { African American } \\
\text { total sample } M(S D)\end{array}$ & $\begin{array}{c}\text { White total } \\
\text { sample } M(S D)\end{array}$ & By class year & $\begin{array}{c}\text { African American } \\
\qquad M(S D)\end{array}$ & $\begin{array}{l}\text { White } \\
M(S D)\end{array}$ \\
\hline \multirow[t]{4}{*}{ Association } & $3.89(1.12)^{* * *}$ & $4.78(1.21)$ & Freshmen & $4.34(1.56)^{a}$ & $4.96(1.24)^{a}$ \\
\hline & & & Sophomore & $3.96(1.14)$ & $4.46(1.13)$ \\
\hline & & & Junior & $3.72(1.05)$ & $4.82(1.00)$ \\
\hline & & & Senior & $3.84(, 98)$ & $4.43(1.37)$ \\
\hline \multirow[t]{4}{*}{ Equal status } & $4.08(1.09)^{* * *}$ & $5.44(.91)$ & Freshmen & $5.08(1.16)^{a}$ & $5.54(.97)^{a}$ \\
\hline & & & Sophomore & $4.22(1.06)$ & $5.16(.88)$ \\
\hline & & & Junior & $3.90(.90)$ & $5.48(.69)$ \\
\hline & & & Senior & $3.76(1.12)$ & $5.43(.84)$ \\
\hline \multirow[t]{4}{*}{ Interdependence } & $4.06(.92)^{* * *}$ & $4.81(.92)$ & Freshmen & $5.42(1.01)^{a}$ & $5.74(.78)$ \\
\hline & & & Sophomore & $5.05(.88)^{a}$ & $5.62(.86)$ \\
\hline & & & Junior & $4.92(.98)$ & $5.74(.95)$ \\
\hline & & & Senior & $4.95(.88)$ & $6.23(.52)^{a}$ \\
\hline \multirow[t]{4}{*}{ University supportive norms } & $4.06(.92)^{* * *}$ & $4.81(.92)$ & Freshmen & $4.36(1.16)$ & $4.89(.97)$ \\
\hline & & & Sophomore & $4.21(.92)$ & $4.72(.92)$ \\
\hline & & & Junior & $3.83(.74)$ & $4.81(.87)$ \\
\hline & & & Senior & $3.99(.99)$ & $4.60(.83)$ \\
\hline \multirow[t]{4}{*}{ Personal association } & $5.31(1.38)^{* * *}$ & $6.13(.80)$ & Freshmen & $5.78(1.54)$ & $6.10(.90)$ \\
\hline & & & Sophomore & $5.38(1.30)$ & $6.18(.63)$ \\
\hline & & & Junior & $5.14(1.40)$ & $6.13(.72)$ \\
\hline & & & Senior & $5.28(1.40)$ & $6.19(.67)$ \\
\hline
\end{tabular}

Note. The letter $a$ in superscript denotes significant within group differences at $p<.05$ level.

*** Denotes significant group differences at $p<.001$ level. 
Table III. Racial Climate Subscale Inter-Correlations by Race (African American Student Correlations Above the Diagonal, White Student Correlations Below the Diagonal)

\begin{tabular}{lcccccccccc}
\hline & 1 & 2 & 3 & 4 & 5 & 6 & 7 & 8 & 9 & 10 \\
\hline 1. Family income & & $.54^{* *}$ & $-.37^{* *}$ & $-.20^{* *}$ & $.24^{* *}$ & $.16^{*}$ & .12 & -.10 & .04 & .05 \\
2. Mother education & $.36^{* *}$ & & $-.37^{* *}$ & -.12 & $.25^{* *}$ & $.14^{*}$ & .10 & -.06 & .01 & -.04 \\
3. Percentage AA in neighborhood & $-.18^{*}$ & $-.20^{* *}$ & & $.33^{* *}$ & -.10 & .06 & -.11 & .13 & -.07 & .13 \\
4. Percentage AA in high school & -.13 & $-.20^{* *}$ & .12 & & $-.16^{*}$ & $.16^{*}$ & .01 & .02 & -.06 & -.01 \\
5. High school GPA & $.25^{* *}$ & $.33^{* *}$ & $-.18^{*}$ & -.16 & & $-.15^{*}$ & -.04 & -.04 & -.02 & .07 \\
6. Association & -.15 & .06 & .13 & -.06 & .01 & & $.32^{* *}$ & $.47^{* *}$ & $.25^{* *}$ & $.32^{* *}$ \\
7. Equal status & -.01 & .05 & .14 & .02 & -.06 & $.35^{* *}$ & & $.36^{* *}$ & $.24^{* *}$ & $.23^{* *}$ \\
8. Supportive norms & .08 & .07 & .08 & .09 & -.10 & $.46^{* *}$ & $.44^{* *}$ & & $.28^{* *}$ & $.14^{*}$ \\
9. Interdependence & .01 & .13 & -.12 & .12 & -.02 & .14 & $.35^{* *}$ & $.27^{* *}$ & $.29^{* *}$ \\
10. Personal association & -.07 & .08 & $.21^{*}$ & .04 & -.04 & $.27^{* *}$ & .18 & .08 & $.20^{*}$ & \\
\hline
\end{tabular}

${ }^{*} p<.05 .{ }^{* *} p<.01$.

and racial composition of neighborhood and high school were entered as covariates. The overall Model $\mathrm{F}$ was significant $(F=7.65, p<.001)$. Examination of means indicated that African American students held more negative perceptions across all four perception subscales compared to White students. In contrast, White students had higher scores on the personal association subscale. Class year effects were found for association and equal status perceptions. Post hoc comparisons (Duncan's tests) revealed first year students had higher scores on the subscales than other class years. Finally, race $x$ class year effects were found for equal status scores and interdependence scores. With regard to equal status scores, African American freshmen had more positive perceptions than African American students in all other class years, while no class differences were found for White students. Similarly, African American freshmen and sophomores had higher interdependence scores than African American junior and seniors. In contrast, White seniors had higher interdependence scores than White students in other class years.

Table III presents inter-scale correlations for student background and racial climate variables for African Americans and Whites. Moderate, positive relationships were found among the racial climate factors across sample groups. In general, few relationships were found between student background variables and the racial climate variables. The two groups, however, did differ in a few respects. Having higher numbers of African Americans in their neighborhood was related to more personal intergroup association on campus among Whites. For African American students, family income, mother education, and percentage of African Americans in high school were positively correlated with perceived intergroup associations on campus. A negative rela- tionship with association was found for high school GPA.

The samples also differed in relationships among some racial climate variables. For African American students, a significant, positive relationship was found between association and interdependence. For White students, the correlation between the two variables was non-significant. Further group differences emerged between personal association and other racial climate variables. For White students, personal association with other racial groups related to perceiving intergroup associations on campus and to group interdependence. For African Americans, personal association showed significant, positive relationships with all other racial climate variables.

\section{Group Differences in Campus Interaction and Social Integration Variables}

\section{Organizational Involvement}

African Americans and Whites differed significantly in whether they were involved in organizations at all, with 38 White students $(26 \%)$ reporting being involved in no organizations and 29 African American students $(13 \%)$ reporting no organizational involvement $\left(\chi^{2}=11.19, p<.001\right)$. Sample sizes for analyses related to organizational involvement, therefore, are based on students participating in at least one organization $(N=106$ White students and $N=186$ African American students). A series of T-tests were conducted to compare involved and non-involved students on all study variables. Results showed that students who were involved in at least one organization were higher in class year than those reporting no organizational involvement $(t=-2.05$, $p<.01)$. Involved students had a higher mean score 
on other-group orientation $(t=-2.12, p<.05)$. The involved and non-involved groups also differed on perceptions of equal status among racial groups on campus $(t=1.54, p<.05)$. Those involved in no organizations had a higher mean score $(M=4.85$, $S D=1.06)$ than those involved in at least one organization $(M=4.56, S D=1.25)$.

To examine race group differences in organizational involvement variables, Analysis of Covariance (ANCOVA) was conducted with the total percentage of organizations as the dependent variable. Student demographic background factors and class year were included as covariates. The overall model was significant $(F=10.09, p<.001)$. The racial groups differed in their total number of organizations $(M=$ $1.90, S D=1.62$ for Whites and $M=2.22, S D=$ 1.53 for African Americans). While groups could not be compared statistically on intergroup organizational variables (as different organizational variables were used for each group), it does appear that groups did differ in their organizational involvement. African American students' mean percentage of group affirming organizations or multicultural organizations was $51.71 \%(S D=40.42) .12 .32 \%$ of White students' organizations were ethnically diverse $(S D=27.65)$.
ANCOVAs also were conducted to examine racial group differences in other-group orientation and sense of community (covarying student background variables). The groups did not differ significantly on other-group orientation scores, but they did differ in sense of community scores $(F=32.6$, $p<.001)$. White students reported higher sense of community $(M=4.84, S D=.87)$ than did African Americans $(M=4.31, S D=.87)$.

\section{Racial Climate and Social Integration/Intergroup Outcomes}

In order to establish external validity of the racial climate measure, hierarchical regression analyses were conducted to examine the relationship of student background and racial climate factors on intergroup outcomes (organizational involvement, other group orientation) and overall social integration (sense of community). In each model, student background variables and class year were entered into the first block and racial climate factors in a second block. Separate models were tested for the African American and White samples. Tables IV and V summarize these analyses.

Table IV. Summary of Regression Models: Social Adjustment Outcomes Regressed on Student Background and Racial Climate Factorsfor White Students

\begin{tabular}{|c|c|c|c|c|c|c|}
\hline & \multicolumn{2}{|c|}{ Sense of community } & \multicolumn{2}{|c|}{$\begin{array}{c}\text { Percentage diverse/cultural } \\
\text { organizations }\end{array}$} & \multicolumn{2}{|c|}{$\begin{array}{l}\text { Other group } \\
\text { orientation }\end{array}$} \\
\hline & $\beta$ & $\beta$ & $\beta$ & $\beta$ & $\beta$ & $\beta$ \\
\hline \multicolumn{7}{|l|}{ 1. Background factors } \\
\hline Class year & $-.31^{* *}$ & $-.22^{* *}$ & $.20^{*}$ & .20 & -.13 & -.15 \\
\hline Income & $.21^{* *}$ & $.18^{*}$ & -.07 & -.14 & .02 & .03 \\
\hline Mother's education & .04 & .03 & -.04 & -.08 & .06 & .03 \\
\hline High school GPA & -.10 & -.06 & .06 & .13 & .03 & .06 \\
\hline $\begin{array}{l}\text { Percentage African } \\
\text { Americans in high school }\end{array}$ & .06 & .03 & .03 & -.02 & .03 & .03 \\
\hline $\begin{array}{l}\text { Percentage African } \\
\text { Americans in neighborhood }\end{array}$ & .03 & -.08 & .09 & -.05 & .14 & .09 \\
\hline Statistics for step $R^{2}$ & .13 & & .07 & & .04 & \\
\hline \multicolumn{7}{|l|}{ 2. Racial climate factors } \\
\hline Association & & -.01 & & $-.21^{*}$ & & -.03 \\
\hline Equal status & & $.48^{* * *}$ & & .01 & & -.01 \\
\hline Interdependence & & $-.20^{* *}$ & & $.30^{* *}$ & & -.09 \\
\hline Supportive norms & & .12 & & -.13 & & .05 \\
\hline Personal association & & -.05 & & $.22^{* *}$ & & $.34^{* * *}$ \\
\hline \multicolumn{7}{|l|}{ Statistics for step } \\
\hline$R^{2}$ & & .37 & & .16 & & .16 \\
\hline$\Delta R^{2}$ & & .24 & & .09 & & .12 \\
\hline
\end{tabular}

Note. In the regression model predicting percent multicultural organizations, participants' total number of organizations also was included as control variable.

${ }^{*} p<.05 .{ }^{* *} p<.01 .{ }^{* * *} p<.001$. 
Table V. Summary of Regression Models: Social Adjustment Outcomes Regressed on Student Background and RacialClimate Factors for African American Students

\begin{tabular}{|c|c|c|c|c|c|c|}
\hline & \multicolumn{2}{|c|}{ Sense of community } & \multicolumn{2}{|c|}{$\begin{array}{l}\text { Percentage diverse/ } \\
\text { cultural organizations }\end{array}$} & \multicolumn{2}{|c|}{$\begin{array}{l}\text { Other group } \\
\text { orientation }\end{array}$} \\
\hline & $\beta$ & $\beta$ & $\beta$ & $\beta$ & $\beta$ & $\beta$ \\
\hline \multicolumn{7}{|l|}{ 1. Background factors } \\
\hline Class year & -.11 & .01 & .10 & .01 & -.08 & -.06 \\
\hline Income & .05 & .07 & -.07 & .01 & .07 & .05 \\
\hline Mother's education & .04 & .01 & -.01 & -.06 & -.05 & -.03 \\
\hline High school GPA & -.05 & .02 & -.08 & -.06 & .03 & -.02 \\
\hline $\begin{array}{l}\text { Percentage African } \\
\text { Americans in high school }\end{array}$ & .03 & .06 & -.08 & -.06 & .09 & .12 \\
\hline $\begin{array}{l}\text { Percentage African } \\
\text { Americans in neighborhood }\end{array}$ & -.04 & -.04 & .01 & .02 & -.15 & -.12 \\
\hline Statistics for step & & & & & & \\
\hline$R^{2}$ & .03 & & .13 & & .04 & \\
\hline \multicolumn{7}{|l|}{ 2. Racial climate factors } \\
\hline Association & & -.08 & & .11 & & $-.22^{* *}$ \\
\hline Equal status & & $.18^{* *}$ & & $-.24^{* *}$ & & -.03 \\
\hline Interdependence & & $.40^{* * *}$ & & .06 & & $.43^{* * *}$ \\
\hline Supportive norms & & $.19^{* *}$ & & .03 & & $.19^{* *}$ \\
\hline Personal association & & -.09 & & -.08 & & $.43^{* * *}$ \\
\hline \multicolumn{7}{|l|}{ Statistics for step } \\
\hline$R^{2}$ & & .27 & & .18 & & .22 \\
\hline$\Delta R^{2}$ & & .24 & & .05 & & .18 \\
\hline
\end{tabular}

Note. In the regression model predicting percent multicultural organizations, participants' total number of organizations also was included as control variable in block 1.

${ }^{*} p<.05 .{ }^{* *} p<.01 .{ }^{* * *} p<.001$.

\section{Organizational Involvement}

To assess the relation between racial climate perceptions and involvement in multigroup organizations, students' percentage of organizations that were diverse with regard to ethnicity was regressed on background and racial climate variables for White students (See Table IV). The predictive model with background variables only was non-significant $(F=$ $1.38, n s)$. A significant model did result when the racial climate variables were added $(F=2.07, p<$ $.05)$ and accounted for an additional $9 \%$ of variance in multicultural organizational involvement. In the final model, univariate analyses showed positive relationships with class year $(\beta=.20, p<.05)$, perceptions, interdependence $(\beta=.30, p<.01)$ and personal intergroup association $(\beta=.22, p<.05)$. Multicultural organizations were negatively related to perceptions of intergroup association on campus $(\beta=.21, p<.05)$.

For African American students, percentage of ethnic group affirming or multicultural organizations was the dependent variable (See Table V). Student background factors did not contribute significantly to the variance accounted for in groupaffirming/multicultural organizational involvement.
Adding the racial climate block resulted in a significant model that accounted for an additional 5\% of the variation in group-affirming organizations. Only equal status scores were related to organizational involvement, with lower equal status scores related to participation in more group-affirming or diverse organizations $(\beta=-.24, p<.01)$.

\section{Intergroup Orientation}

The model predicting students' other group orientation was significant for White students $(F=$ $1.83, p<.05)$, and adding the racial climate variables resulted in an increment increase of $12 \%$ of variance accounted for in other group orientation. Personal intergroup association was related to high other group orientation scores $(\beta=.34, p<.001)$. For African American students, a significant model also resulted when racial climate variables were entered $(F=5.16, p<.001)$, accounting for an additional $18 \%$ of variance in other-group orientation $\left(R^{2}=22\right)$. Perceptions of campus intergroup association were negatively related to other group orientation $(\beta=-.22, p<.01)$, while university norms and personal association mean scores were related to 
higher other-group orientation $(\beta=.19, p<.01$ and $(\beta=.43, p<.001$, respectively).

\section{Sense of Community}

Finally, the relationship between students' racial climate perceptions and their overall sense of community on campus was examined. For White students, family income was related to having a higher sense of community $(\beta=.21, p<.01)$, while class year was negatively related to sense of community $(\beta=-.30, p<.001)$. The racial climate variables block increased the variance accounted for in sense of community from 13 to $37 \%$ (overall Model $F=$ $6.91, p<.001)$. Equal status perceptions were positively related to sense of community $(\beta=.48, p<$ .001 ), and perceived group interdependence was related to lower sense of community $(\beta=-.20, p<$ .01). For African American students, student background did not contribute significantly toward variance accounted for in sense of community. The racial climate variables increased the variance accounted for an increment of $24 \%$. Students' perceptions of equal status $(\beta=.18, p<.01)$, university supportive norms $(\beta=.19, p<.01)$, and interdependence $(\beta=.40, p<.001)$ were positively related to sense of community.

\section{DISCUSSION}

The present investigation assessed the ways that African American and White PWI students perceive the racial climate on their campus, using a framework based on Allport's intergroup contact theory. Focusing on students' perceptions of the quantity and quality of intergroup interactions on campus at interpersonal and institutional levels allowed for a more complex picture of the ways that students from different ethnic and social backgrounds experienced race and race relations. Issues of race and race relations in America's educational systems have continued to be prominent since the school integration efforts of the 1950s and 1960s. The discussion of such issues is particularly relevant in light of current debates around race and affirmative action policy in college admissions and the value and impact of diversity in higher education (e.g., Gurin et al., 2002). More recently, Gurin and colleagues (2002) analyzed national college samples and conducted a comprehensive review of university studies related to campus racial composition and diversity. They found that students having meaningful diversity experiences (e.g., intergroup interactions) on campus related to outcomes very relevant to the field of community psychology: intellectual engagement, motivation to think actively about social phenomena; commitment to promoting racial understanding; perspective taking; sense of commonalty with others; and involvement in political affairs. Their review suggested that these outcomes were not only limited to the time that students were in college but to longer term personal intergroup association as well. The present study findings provide complementary evidence that the ways students perceive their institutions' norms and values and philosophies around race and the contribution of different racial groups have implications for the nature of students' interpersonal diversity experiences on campus.

\section{Influences of Student Demographic Background}

Students' prior experiences influence their perceptions and interpretations in new settings. College student development theory and intergroup research with college students assert that individuals' precollege characteristics influence the ways they experience and integrate into their college setting (e.g., Tinto, 1975, 1987; Pascarella et al., 1996). Differences between African American and White students' college outcomes often have been attributed to differences in their demographic backgrounds, with an emphasis on socioeconomic differences (Tinto, 1987), as well as adjustment difficulties related to minority students coming from more race-homogenous backgrounds to ones in which they are a racial and social minority (D'Augelli \& Hershberger, 1993). In the present study, African American students had significantly lower family income levels than did their White counterparts, but they were similar in mother's education levels. With regard to racial background, African American students were more likely than White students to come from environments with racial compositions that differed from their college environment, although neither sample came from totally race homogenous backgrounds.

Prior intergroup contact may influence African American and White students' college perceptions in different ways, however, as their prior intergroup contact likely occurred under different conditions. African American and White students from more affluent family backgrounds are more likely 
to come from backgrounds that are predominantly White than their counterparts from less affluent backgrounds, and poorer African American students are especially more likely to come from more racehomogenous backgrounds (Chavous, Rivas, Green, \& Helaire, 2002; McAdoo, 1997). Results showed that African American students from more affluent backgrounds perceived more intergroup relations on campus. In contrast, African American students coming from high schools with more African Americans also perceived more intergroup associations. While the findings may seem contradictory, the relationship with college intergroup perceptions for African American students from more affluent, predominantly White neighborhoods may reflect their prior intergroup experiences. African American students coming from more race-homogenous environments may view a predominantly White college environment as having more intergroup interactions relative to their previous intergroup experiences. The fact that students' backgrounds did not relate to other racial climate factors suggests, however, that the racial congruence or incongruence between their background and their college does not necessarily influence their views of the quality of those interactions, institutional values, nor their own intergroup associations. The reality that they are statistical minorities on their campus may force African American students at predominately White institutions, regardless of background, to interact to some degree with White students. For instance, classes and labs, academic group projects, academic clubs, and meals at dining halls may result in frequent interactions with Whites regardless of individuals' racial background.

For White students, however, such involuntary intergroup associations and reciprocal interactions occur less frequently, thus their personal intergroup interactions are more likely to result from voluntary behaviors (Powers \& Ellison, 1995). Because the PWI setting more closely matches the racial backgrounds of most of the White students in the study it would be very easy for them to replicate their home/high school environments and only interact with members of their own group. Students who have had precollege racial experiences (interactions, friendships) with African Americans before college may be more likely to initiate or be open to interactions with African Americans on campus compared to White students who have had little or no contact with African Americans prior to college (Pascarella et al., 1996; Whitt et al., 2001).

\section{Relationships Among Racial Climate Factors}

Racial group differences in how individuals think about and perceive race relations on campus across multiple areas also may play an important role in the group differences in relationships among racial climate factors. Although the factor structure of the present racial climate scale was similar for Blacks and Whites, the different correlations among the factors suggest differences in how the groups perceived and made meaning of intergroup interactions. For African Americans, perceiving more intergroup associations on campus was related to perceiving more group interdependence. In contrast, for White students, perceiving intergroup association was not related to group interdependence. One interpretation is that viewing Black and White students as needing and benefiting from one another result from actual intergroup interactions for African American students, while for White students, feeling that groups need one another may not relate to their actual intergroup experiences. Nora and Cabrera (1994) suggest African American students may have more "nuanced" views of race on campus than White students due to the salience of race in these settings. Thus, African American students may be more attuned to experiences and issues that convey messages about race and diversity norms than their White counterparts. Furthermore, integrating into an environment in which they are the numerical and social minority is more likely to involve having positive relationships with members of other groups for African American students. For White students, though, the way race functions on campus may be less directly salient to their social experiences, thus their views of interdependence among groups on campus may be based on less specific race-related experiences and observations (e.g., Lopez, Gurin, \& Nagda, 1998).

One especially relevant finding was that both groups' personal intergroup associations were related to their perceiving intergroup associations as a normative behavior on campus as well as to perceiving interdependence between African Americans and Whites on campus. Although the cross-sectional nature of the study precludes any conclusions regarding the direction of causality, the findings are consistent with the idea that institutional norms regarding intergroup interactions shape students' own intergroup behaviors other research indicates that students are racially socialized by their campus environment from the very beginning of their tenure at the institution (Baldwin, Rackley, \& Brown, 1990; 
Nagda et al., 2004). It also is possible that the causal direction is reversed such that students' personal intergroup experiences impact their beliefs regarding institutional norms around intergroup interaction. Research has found that individuals' previous racial experiences influence their perceptions of racial climate. It is most likely, however, that the relationship is bi-directional, such that students' environmental perceptions shape their social interaction behaviors and that their social behaviors affect their perceptions. Future longitudinal research is needed before definitive conclusions regarding the direction of causality can be made.

\section{Racial Climate Perceptions and College Integration Outcomes}

Although students' precollege backgrounds did relate to racial climate perceptions to a small extent, overall, background was not strongly related to racial climate perceptions or to integration outcomes on campus for African Americans or Whites. Instead, institutional racial climate seemed to have a stronger association with views of the extent and ways that students from different groups interacted. The study findings also suggest that racial climate perceptions may function similarly in some respects for African American and White students, but differently in other respects.

\section{Organizational Involvement}

African American students who saw unequal status between African Americans and Whites were involved in more African American organizations. Researchers consistently have asserted the importance of social integration in students' academic experiences, especially for minority students (e.g., Suen, 1983). At PWIs, most organizations are predominantly White. Many organizations involve professional affiliations or curricular activities (e.g., honor societies, pre-medical organizations, psychology club). Therefore, African American students may be likely to become a part of a mainstream organization, regardless of their perceptions of the racial climate. With regard to involvement in African American predominant organizations, the link with unequal status is consistent with the view that the group-affirming organizations serve as social support or buffering agents in the face of racial isolation or discrimination (Buttny, 1999; Chavous, 2000).
White students who perceived interdependence among racial group members and those who had more personal intergroup association were involved in more diverse/race-mixed organizations. The lack of own-group organizations or feelings of social isolation is less likely to influence White students' selections of racially mixed organizations. Instead, their involvement may reflect desires to learn about multicultural issues and interact with other groups, as many racially mixed or minority-group predominated organizations are centered on issues of diversity, ethnicity, or culture (e.g., minority coalition/activist organizations). An alternative explanation is that White students who are involved in multicultural organizations may have more contact with other race groups and, in turn, have racial climate perceptions that are more similar to those groups.

\section{Other Group Orientation}

The study findings for other social outcomes also suggest different integration processes for African Americans and Whites related to racial climate perceptions. For both groups, having more personal intergroup interactions related to reporting more exploration and valuing of other groups' experiences. However, personal association was the only significant predictor of other group orientation for Whites. For African Americans, perceiving group interdependence as well as viewing intergroup interactions as normative on campus also predicted other-group orientation. Researchers applying intergroup contact theory to research with ethnic minority samples suggest the impact of intergroup associations is not equivalent across ethnic groups (Sigelman \& Welch, 1993; Shelton, 2001). White students at PWIs are likely to have very little intergroup interaction or exposure to African Americans prior to college (Pewewardy \& Frey, 2002), and even on PWI college campuses, researchers report that many White students have relatively little interaction with other ethnic/racial groups. Thus, having some personal contact with another group member may be sufficient to influence intergroup attitudes. In contrast, it is unlikely that African Americans on PWI campuses have not been exposed to or engaged in interactions with Whites, as they are likely to have had White teachers (even within predominantly Black secondary schools), student peers, class project groups, etc, as well as substantial media exposure (TV, movies, etc.). Consequently, their intergroup 
attitudes would be influenced less by personal contact alone than by contact that is based on meaningful associations (i.e., based on interdependence) (Jones et al., 2000; Pettigrew, 1998; Powers \& Ellison, 1995; Sigelman \& Welch, 1993).

\section{Sense of Community}

Perceptions of interdependence, equal status, and supportive university norms were related to higher sense of community for African Americans. In contrast, perceiving group interdependence was related to having a lower sense of community for Whites. One possibility for the striking difference is that for White students who do not perceive Whites interacting with African Americans as a normative occurrence on campus, viewing African Americans and Whites as interdependent may result in their feeling disconnected from the larger PWI environment. In organizational research, perceiving one's values or beliefs as different from the perceived philosophies and norms of one's environment results in less identification with that environment as a whole (e.g., Dutton, Dukerich, \& Harquail, 1994). (This reasoning was supported in post hoc regression analyses conducted by the author, where a significant association $\times$ interdependence interaction was found in predicting sense of community for Whites, but not for African Americans). In contrast, for African Americans, perceiving group interdependence, or feeling as though their group is valued and makes an equally valuable contribution on campus, may lead to stronger feelings of institutional identification.

In considering the application of intergroup theory to the study findings as a whole, it appears that beyond students' demographic backgrounds, perceptions of intergroup norms and institutional supports of those norms have a substantial association with the social adjustment and behaviors of its members. The findings from the present study suggest the need for future research on the ways students' group identity orientations interact with the philosophies of their college contexts. Although Whites had more positive racial climate views than Blacks, intergroup experiences were not unimportant to White students' perceptions of the racial climate nor to their integration outcomes. White students' perceptions and integration outcomes, however, were related more to perceptions of intergroup interactions at the interpersonal level, while both interpersonal and institutional level factors were salient to African
American students' social and psychological integration. The discussion of individualism by Lopez et al. (1998) could help explain group differences in perceptions and relationships found in the present study. In a society that values individualism, thinking about structural influences (e.g., institutional discrimination) may be more difficult and less likely for majority group members. Research on attribution biases suggests that Western cultures emphasize individualistic explanations of discrimination, while in other cultures, situationally sensitive and structural explanations are more common (Lopez et al., 1998). While they exist in a Western society, research has shown that African Americans are more likely than Whites to hold collectivist beliefs (Jones, 1994), thus, they may take a less individualistic perspective in thinking about race on campus. Instead, their ideas about inequality are more likely to derive from ideas about causation that involve larger social contexts and that are shared with others (Lopez et al., 1998). Furthermore, White students who perceived different groups as interdependent but perceived that intergroup association was not a campus norm felt lower sense of community. For some White students, there may be a social cost for deviating from an individualistic orientation and taking on a more multi-group orientation.

Similarly, a racial climate that is not supportive of positive intergroup relations may result in African American students feeling pulled to choose between a group versus an individual orientation. Buttny (1999) discusses the conflict some African American students experience between their desire to integrate into the PWI environment and their desire to maintain group solidarity and group identity on campus. Based on their exclusion from mainstream social outlets, some African American students may perceive significant interactions with other racial and ethnic groups as unacceptable. Their perceptions may be reinforced by communication from African American peers who view crossing intergroup boundaries as behavior that threatens group solidarity (Buttny, 1999; Giles \& Coupland, 1992). In the present study, students perceiving unequal status who become involved in group-predominant organizations may be able to maintain a sense of solidarity and received needed support, but for some, it also may reinforce perceived differences between groups (Kelly et al., 1994). In contrast, students who perceive intergroup interactions as a campus norm and racial groups as interdependent may feel more free to engage in intergroup behaviors (i.e., higher other-group orientations) without fear of lessening 
own group ties (Jones et al., 2000). This reasoning is consistent with research by Watts and Carter (1991), which shows relationships between African Americans' racial identity beliefs and perceptions of racial climate in organizational settings. Clearly, more research is needed on the congruence between individuals' cultural orientations and their perceived college environment across and within ethnic groups before definitive conclusions can be made. Such research could build upon the present findings.

\section{Limitations and Considerations}

When considering the study findings, several points should be made to qualify interpretations and conclusions made. One is that students may form other types of support networks and connections in response to their perceptions of the college environment than those evaluated in this research. Therefore, though a student may not be involved in many school organizations or feel a sense of connection to the larger college environment, he/she may feel supported by informal networks, such as peer and friendship groups. Research that examines the approaches that today's students utilize in integrating into college and forming friendships, as well as perceived barriers to these processes would be an important compliment and building block for psychological and educational research. Furthermore, the use of qualitative methods (ethnographic study, focus groups, interviews) as well as longitudinal quantitative designs could help shed light on students' psychosocial and developmental processes.

Another consideration in interpreting study findings is that examining intergroup interactions (before and during college) in terms of contact between African Americans and Whites may obscure information about individuals' interracial contact with other groups. Though some students may report being in organizations or coming from high schools with small percentages of African American students, they may have interacted with Latino/a or Asian American students in these settings. Therefore, individuals' interracial experiences may be underestimated. ${ }^{3}$ In studying college racial climate in regions where greater ethnic diversity exists in

\footnotetext{
$\overline{{ }^{3} \text { The racial composition of the university and its surrounding re- }}$ gion, as well as students' regional, neighborhood, and high school backgrounds, make it likely that their intergroup experiences primarily were between African Americans and Whites.
}

student background and college population, it would be necessary to incorporate multiple groups into assessments of the nature and quality of intergroup associations.

It also may be possible that hypothesized relationships may differ for some students over time. For instance, class year may be a moderating influence in the relationships among background, racial climate, and intergroup interaction outcomes. Study findings showed class year was associated with racial climate for African American students and with social outcome variables for African American and White students. African American freshmen and sophomores had more positive perceptions along several racial climate factors than their upperclass counterparts. White students showed this pattern, but to a lesser extent, as they were more similar in perceptions across class years overall. African American students from race-homogenous backgrounds may perceive their new campus environment more positively (e.g., university efforts to welcome students, substantial interaction with Whites in class and social settings for the first time) than older students who have had a chance to learn more about race and campus norms or be socialized by peer groups. The relationships among the study constructs may differ not only between racial groups, but also within groups for students in different stages of their college experience. Students' social and racial backgrounds may have a stronger impact on social perceptions, attitudes, and behaviors for students just entering the college environment than for those who have had more time to adapt to the college environment. Furthermore, older students may be able to view the campus climate differently and respond to it differently as they integrate previous experiences on campus (Graham, 1998). This reasoning cannot be fully supported from data in the present study, given the cross-sectional nature of the study design. Future longitudinal research is necessary to illuminate intra-individual development resulting from contextual experience.

A final consideration is that because students from only one PWI were examined at one time period, findings cannot be generalized to all PWIs. Future research including samples from multiple institutions is needed. In addition, because the sample was disproportionately female, explorations of gender differences among study constructs and relationships were not possible but may be important in considering future directions. Fleming (1984) and Davis (1995) assert that African American males fare worse socially and academically then their female 
counterparts at PWIs. Furthermore, research on race attitudes among White college students suggests that males and females differ in levels of conservatism (Sydell \& Nelson, 1998) and that White females are more likely to identify with other social minority groups than White males (e.g., Astin, 1993; Canabal, 1993; Johnson-Durgans, 1994; Levine \& Cureton, 1998).

\section{CONCLUSIONS}

Even considering the above issues, the present research suggests the importance of conceptualizing and operationalizing students' perceptions of racial climate in more complex ways. Such an approach provides greater evidence that students' perceptions of the ways race functions in their campus environment are relevant contributions to research models seeking to explain students' college experiences. One implication is that fostering learning environments and communities where all students feel included and valued is an important outcome in itself. In student transition interventions, student retention programs, and multicultural or diversity initiatives, information about the role of race and race perceptions for minority and majority students is needed. It is important to include all groups, not just the minority groups that often are targeted in student transition interventions or the majority students who often are targeted in prejudice-reducing or tolerance efforts (Kelly et al., 1994). Racial climate, whether it exists in a university community or in a larger community, is based on interactions among individuals across groups, not only within a single group targeted for intervention. Therefore, the experiences and perceptions of members of different groups should be included in efforts to understand and improve the climate.

\section{ACKNOWLEDGMENTS}

This study was supported by a National Institutes of Health National Research Service Award and an American Psychological Association Dissertation Award. The author also acknowledges support and time through grant funding from the Spencer Foundation.

\section{REFERENCES}

Allen, W. R. (1988). Black students in U.S. higher education: Toward improved access, adjustment, and achievement. Urban Review, 20, 165-188.
Allport, G. W. (1954). The nature of prejudice. New York: Anchor.

Ancis, J., Sedlacek, W., \& Mohr, J. (2000). Student perceptions of campus cultural climate by race. Journal of Counseling \& Development, 78(2), 180-185.

Astin, A. (1993). Diversity and multiculturalism on campus: How are students affected? Change, 25(2), 44-49.

Baldwin, J., Rackley, R., \& Brown, R. (1990). Some sociobehavioral correlates of African self-consciousness in African-American college students. Journal of Black Psychology, 17(1), 1-17.

Baxter Magolda, M. B. (1997). Facilitating meaningful dialogues about race. About Campus, 2(5), 14-18.

Bennett, C. (1984). Interracial contact experience and attrition among Black undergraduates at a predominantly White university. Theory and Research in Social Education, 12(2), 1947.

Berndt, T. J. (1979). Developmental changes in conformity to peers and parents. Developmental Psychology, 15, 608-616.

Blauner, B. (1989). Black lives, white lives: Three decades of race relations in America. Berkeley, CA: University of California Press.

Brewer, M. (1996). When contact is not enough: Social identity and intergroup cooperation. International Journal of Intercultural Relations, 20, 291-303.

Bullock, C. S. (1978). Contact theory and racial tolerance among high school students. School Review, 86(2), 187-216.

Buttny, R. (1999). Discursive constructions of racial boundaries and self-segregation on campus. Journal of Language and Social Psychology, 18(3), 247-268.

Cabrera, A., Nora, A., Terenzini, P., Pascarella, E., Hagedorn, L., \& Serra, L. (1999). Campus racial climate and the adjustment of students to college: A comparison between White students and African-American students. Journal of Higher Education, 70(2), 134-160.

Canabal, M. E. (1993). An assessment of institutional attractiveness by race/ethnicity and gender in a midwestern public baccalaureate institution. College Student Journal, 27(1), 85-95.

Chavous, T. M. (2000). The relationships among racial identity, perceived ethnic fit, and organizational involvement for African American students at a predominantly White university. Journal of Black Psychology, 26(1), 79-100.

Chavous, T., Rivas, D., Green, L., \& Helaire, L. (2002). The roles of student social and economic background, perceptions of ethnic fit, and racial identification in the academic adjustment of African American college students. Journal of Black Psychology, 28(3), 234-260.

Cook, S. W. (1985). Experimenting on social issues: The case of school desgregation. American Psychologist, 40, 452-460.

Crocker, J., \& Luhtanen, R. (1990). Collective self-esteem and ingroup bias. Journal of Personality and Social Psychology, 58, 60-67.

D’Augelli, A. R., \& Hershberger, S. L. (1993). African American undergraduates on a predominantly White campus: Academic factors, social networks, and campus climate. Journal of Negro Education, 61(1), 67-81.

Davis, J. E. (1995). College in Black and White: Campus environment and academic achievement of African American males. Journal of Negro Education, 63(4), 620-633.

Dutton, J. E., Dukerich, J. M., \& Harquail, C. V. (1994). Organizational images and member identification. Administrative Science Quarterly, 39(2), 239-263.

Edmonds, G. J. (1984). Needs assessment strategy for Black students: An examination of stressors and program implications. Journal of Non-White Concerns, 12, 48-56.

Essed (1991). Understanding everyday racism. Newbury Park, CA: Sage.

Fleming, J. (1984). Blacks in college: A comparative study of students' success in black and white institutions. San Francisco, CA: Jossey-Bass. 
Gaertner, S. L., Rust, M. C., Dovidio, J. F., Bachman, B. A., \& Anastasio, P. A. (1994). The contact hypothesis: The role of common ingroup identity on reducing intergroup bias. Small Group Research, 25, 224-249.

Giles, H., \& Coupland, N. (1992). Language: Contexts and consequences. Pacific Grove, CA: Brooks/Cole Publishing.

Graham, S. W. (1998). Adult growth in college: The effects of age and educational ethos. Journal of College Student Development, 39, 239-250.

Gray-Little, B., \& Carels, R. A. (1997). The effect of racial dissonance on academic self-esteem and achievement in elementary, junior high, and high school students. Journal of Research on Adolescence, 7(2), 109-131.

Green, C. W., Adams, A. M., \& Turner, C. W. (1988). Development and validation of the school interracial climate scale. American Journal of Community Psychology, 16(2), 241259.

Guion, R. (1973). A note on organizational climate. Organizational Behavior and Human Performance, 9, 120-125.

Gurin, P., Dey, E., Hurtado, S., \& Gurin, G. (2002). Diversity and higher education: Theory and impact on educational outcomes. Harvard Educational Review, 72(3), 330-366.

Halpin, A. W., \& Croft, D. B. (1963). The organizational climate of schools. Chicago: Midwest Administration Center, University of Chicago.

Harvey, W. B. (2001). Minorities in higher education 2000-2001: Eighteenth annual status report. Washington, DC: American Council on Education.

Helm, E., Sedlacek, W., \& Prieto, D. (1998). The relationship between attitudes toward diversity and overall satisfaction of university students by race. Journal of College Counseling, 1(2), 111-120.

Hurtado, S. (1992). The campus racial climate: Contexts of conflict. Journal of Higher Education, 63, 539-569.

Hurtado, S. (1994). Graduate school racial climates and academic self-concept among minority graduate students in the 1970s. American Journal of Education, 102(3), 330-351.

Hurtado, S., Engberg, M., Ponjuan, L., \& Landreman, L. (2003). Students' precollege preparation for participation in a diverse democracy. Research in Higher Education, 43(2), 163-186.

Johnson-Durgans, V. D. (1994). Perceptions of racial climates in residence halls between African-American and Euroamerican college students. Journal of College Student Development, 35(4), 267-274.

Jones, J. M. (1994). The African American: A duality dilemma? In W. J. Lonner \& R. Malpass (Eds.), Psychology and culture (pp. 17-23). Boston: Allyn \& Bacon.

Jones, J. M., Lynch, P. D., Tenglund, A. A., \& Gaertner, S. L. (2000). Toward a diversity hypothesis: Multidimensional effects of intergroup contact. Applied and Preventive Psychology, 9, 53-62.

Kelly, J. G., Azelton, L. S., Burzette, R., \& Mock, L. O. (1994). Creating social settings for diversity: An ecological thesis. In E. J. Trickett, R. J. Watts, \& D. Birman (Eds.), Human diversity: Perspectives on people in context. San Francisco: JosseyBass.

Kluegel, J. R., \& Bobo, L. (1993). Dimensions of whites' beliefs about the black-white socio-economic gap, In P. M. Sniderman, P. E. Tetlock, \& E. G. Carmines (Eds.), Prejudice, politics, and the American dilemma (pp. 127-147). Stanford, CA: Stanford University Press.

Levine, A., \& Cureton, J. S. (1998). Student politics: The new localism. Review of Higher Education, 21, 137-150.

Loo, C. M., \& Rolison, G. (1986). Alienation of ethnic minority students at a predominantly White university. Journal of Higher Education, 57, 59-77.

Lopez, G. E., Gurin, P., \& Nagda, B. A. (1998). Education and understanding structural causes for group inequalities. Journal of Political Psychology, 19(2), 305-329.
Lounsbury, J., \& DeNeui (1996). Collegiate psychological sense of community in relation to size of college/university and extroversion. Journal of Community Psychology, 24(4), 381-394.

Marcus-Newhall, A., \& Heindl, T. R. (1998). Coping with interracial stress in ethnically diverse classrooms: How important are Allport's contact conditions? Journal of Social Issues, 54(4), 813-830.

Martin, J. N., Hecht, M. L., \& Larkey, L. K. (1994). Conversational improvement strategies for interethnic communication: African American and European American perspectives. Communication Monographs, 61, 236-255.

McAdoo, H. P. (1997). Upward mobility across generations in African American families. In H. P. McAdoo (Ed.), Black families (3rd ed., pp. 139-162). Thousand Oaks, CA: Sage.

Nagda, B. A., Gurin, P., \& Johnson, S. M. (2004). Living, doing, and thinking diversity: How does precollege diversity affect first-year students' engagement with college diversity? In R. S. Feldman (Ed.), Improving the first year of college: Research and practice. Mahwah, NJ: Lawrence Erlbaum Associates.

Nettles, M. T. (Ed.). (1988). Toward black undergraduate student equality in American higher education. New York: Greenwood Press.

Nettles, M. T. (1991). Racial similarities and differences in the predictors of college student achievement. In W. R. Allen, E. Epps, \& N. Z. Haniff (Eds.), College in Black and White (pp. 75-91). Albany, NY: State University of New York Press.

Nora, A., \& Cabrera, A. F. (1994). The role of perceptions in prejudice and discrimination and the adjustment of minority students to college. Journal of Higher Education, 67(2), 119-148.

Pargament, K. I., Silverman, W., Johnson, S., Echemendia, R., \& Snyder, S. (1983). The psychosocial climate of religious congregations. American Journal of Community Psychology, 11, 351-381.

Pascarella, E., Edison, M., Nora, A., Hagedorn, L. S., \& Terenzini, P. (1996). Influences on students' openness to diversity and challenge in the first year of college. Journal of Higher Education, 67(2), 174-195.

Pedhazur, E. J., \& Schmelkin, L. P. (1991). Measurement, design, and analysis: An Integrated approach. Hillsdale, N.J.: Lawrence Erlbaum Associates.

Pettigrew, T. F. (1998). Intergroup contact theory. Annual Review of Psychology, 49, 63-85.

Pewewardy, C., \& Frey, B. (2002). Surveying the landscape: Perceptions of multicultural support services and racial climate at a predominantly White university. Journal of Negro Education, 71(1/2), 77-95.

Phinney, J. S. (1992). The multigroup ethnic identity measure: A new scale for use with diverse groups. Journal of Adolescent Research, 7(2), 156-176.

Phinney, J. S., Ferguson, D. L., \& Tate, J. D. (1997). Intergroup attitudes among ethnic minority adolescents: A causal model. Child Development, 68(5), 955-969.

Powers, D. A., \& Ellison, C. G. (1995). Interracial contact and black racial attitudes: The contact hypothesis and selectivity bias. Social Forces, 74(1), 205-226.

Schein, E. (1985). Organizational culture and leadership: A dynamic view. The Jossey-Bass management series and The Jossey-Bass social and behavioral science series. San Francisco, CA: Jossey-Bass Inc.

Shelton, J. N. (2001). A reconceptualization of how we study issues of racial prejudice. Personality and Social Psychology Review, 4(4), 374-339.

Sigelman, L., \& Welch, S. (1993). The contact hypothesis revisited: Interracial contact and positive racial attitudes. Social Forces, $71,781-795$.

Stephan, W. (1987). The contact hypothesis in intergroup relations. In C. Hendrick (Ed.), Group processes and intergroup relations (pp. 13-40). Sage. 
Suen, H. K. (1983). Alienation and attrition of Black college students on predominantly White campus. Journal of College Student Personnel, 19, 117-121.

Sydell, E. J., \& Nelson, E. S. (1998). Gender and race differences in the perceptions of sexual harassment. Journal of College Counseling, 1(2), 99-110.

Tracey, T. J., \& Sherry, P. (1984). College student distress as a function of person-environment fit. Journal of College Student Personnel, 25, 436-442.

Trickett, E. (1996). A future for community psychology: The contexts of diversity and the diversity of contexts. American Journal of Community Psychology, 24(2), 209-234.

Trickett, E., \& Moos, R. H. (1973). Social environment of junior high and high school classrooms. Journal of Educational Psychology, 65(1), 93-102.

Tinto, V. (1975). Dropout from higher education: A theoretical synthesis of recent research. Review of Educational Research, $45,89-125$.
Tinto, V. (1987). Leaving college: Rethinking the causes and cures of student attrition. Chicago: The University of Chicago Press.

Watts, R., \& Carter, R. (1991). Psychological aspects of racism in organizations. Group and organization studies, 16(3), 328344

Whitt, E. J., Edison, M. I., Pascarella, E. T., Terenzini, P. T., \& Nora, A. (2001). Influences on students' openness to diversity and challenge in the second and third years of college. Journal of Higher Education, 72(2), 172-204.

Wittig, M. A., \& Grant-Thompson, S. G. (1998). The utility of Allport's conditions of intergroup contact for predicting perceptions of improved racial attitudes and beliefs. Journal of Social Issues, 54(4), 795812.

Zea, M. C. (1997). Predicting intention to remain in college among ethnic minority and nonminority students. Journal of Social Psychology, 137(2), 149-160. 